\title{
Ratzel's biogeography: a more-than-human encounter
}

\author{
Maan Barua \\ Department of Geography, University of Cambridge, Downing Place, Cambridge, CB2 3EN, UK
}

\begin{abstract}
Understanding the social and political in relation to fabrications of earth/life has been one of geography's most enduring concerns. Friedrich Ratzel's Lebensraum essay, subtitled 'a biogeographical study', is an early exposition of how relations between the bio and the geo are politically molten. Yet his oeuvre, whilst of interest to political geographers, has been overlooked in the recent proliferation of work on the earth/life nexus in more-than-human geography. To this end, this commentary asks what it might mean to read Ratzel's essay in light of attempts to articulate and specify the cartographies of life. Three key themes are highlighted that resonate with contemporary more-thanhuman approaches: the spatial ontologies of animal life, animals' mobilities and cartographies of the living world. More specifically, this commentary expands upon Ratzel's notion of the oecumene and argues that it offers up critical purchase for diagramming animals' ontologies in ways sensitive to geographical concerns with nonhuman difference, lifeworlds and movement. A brief conclusion identifies avenues for future research and engagement.
\end{abstract}

Keywords: Friedrich Ratzel Biogeography More-than-human geography Oecumene Animals Space Mobility

Relations between the bio (life) and the geo (earth) have been amongst geography's most enduring concerns. 'Their durability', Sarah Whatmore has remarked, 'bears the hallmark of geography's history which, like that of archaeology and anthropology, took shape before the now entrenched division between the social and natural sciences took hold'. ${ }^{1}$ It was precisely at such a juncture that Friedrich Ratzel's Lebensraum essay was written, a text that sets up a current that has continued in modern geography's impetus to understand the social and political with and through fabrications of

${ }^{1} \mathrm{~S}$. Whatmore, Where natural and social science meet? Reflections on an experiment in geographical practice, in: A. Barry and G. Born (Eds), Interdisciplinarity: Reconfigurations of the Social and Natural Sciences, Oxford, 2013, 161.

2 F. Ratzel, Lebensraum: a biogeographical study (1901), Journal of Historical Geography 61 (2018) 122. earth/life. ${ }^{2}$ The discipline's productive wrestling with the spatialities, economics and governance of the living and material world, found in the persistence of such themes as landscape, ecology and animal life, stand testimony to this endeavour of examining the bio and the geo in conjunction.

This essay examines one feature of this current: posthumanism, or what have come to be called 'more-than-human' and 'hybrid' geographies, ones that complicate the ontological purity of humanism to honour messy histories and geographies forged by a retinue of other bodies, forces and technologies. ${ }^{3}$ The

3 S. Whatmore, Hybrid geographies: rethinking the 'human' in human geography, in: D. Massey, J. Allen and P. Sarre (Eds), Human Geography Today, Cambridge, 1999, 22-40; S. Whatmore, Hybrid Geographies: Natures, Cultures, Spaces, London, 2002; N. Badmington, Mapping posthumanism, Environment and Planning A 36 (2004) 1341-1363. 
gravitational force of this recent work has now exerted a significant pull on human geography, particularly by questioning routinized ontological beliefs in the discipline. More-thanhuman geographies in the last two decades have sought to rework topologies of the living and material world, diffusing the 'feverish borders' of the social/material and cultural/natural, or, for that matter, animal/machine and flesh/information. ${ }^{4}$ An attention to spaces of embodiment, motion and relation in ways that do not silence, overlay or tidy up the recalcitrant workings of nonhuman life is an impetus shared with non-representational theory and, more recently, strands of neo-vitalism. ${ }^{5}$

Whilst 'life' has predominantly been the domain of biogeography - the branch of geography concerned with documenting and understanding spatial patterns of biodiversity, and of which Ratzel was an early proponent more-than-human geography has sought to engage with questions about the social, political and economic ordering of life through its commitment to understanding entanglements between the bio and the geo. ${ }^{6}$ Almost two decades ago, Tom Spencer and Sarah Whatmore commented that human and biogeographers ought to talk to one another in creative ways, calling for a biogeography 'attuned to the circumstances and anxieties of today's world'. The 'new cartographies of life' they were indexing were those where the bio 'permeate[s] the boundary that has been taken to mark off "human society" from the rest of the "natural world"...'?

Since then, a number of attempts to foster creative conversations have emerged, including

\footnotetext{
${ }^{4} \mathrm{~S}$. Whatmore, Humanism's excess: some thoughts on the 'post-human/ist' agenda, Environment and

Planning A 36 (2004) 1360-1363.

5 N. Thrift, Non-Representational Theory: Space, Politics, Affect, London, 2007; D. Coole and S. Frost, Introducing the New Materialisms, in: D. Coole and S. Frost (Eds), New Materialisms: Ontology, Agency, Politics, Durham NC, 2010, 1-46.

6 J.H. Brown and M.V. Lomolino, Biogeography, second edition, Sunderland MA, 1998.

7 T. Spencer and S. Whatmore, Bio-geographies: putting life back into the discipline, Transactions of the Institute of British Geographers 26 (2001) 140.

8 C.S. Duvall, Human settlement ecology and chimpanzee habitat selection in Mali, Landscape Ecology 23 (2008) 699-716; J. Lorimer, Elephants as companion species: the lively biogeographies of Asian elephant conservation in Sri Lanka, Transactions of the Institute of British Geographers 35 (2010) 491-506; J.A. Stallins and L. Kelley, The embeddedness of a North
}

cultural biogeographies assaying how species distributions are as much the product of histories of colonialism and settlement as they are of ecology; 'lively biogeographies' that seek to incorporate nonhuman difference, agency and vitality into the dynamics and distribution of life articulated by the biogeographical sciences, and 'assemblage biogeographies' that show how organisms' dispersal and speciation are induced through their traffic in international trade. ${ }^{8}$ Others track geomaterialist histories of landscapes foregrounding animal lifeworlds and the burdens of postcolonial subalterns. The relational modes of earth/life writing, or 'bio-geographies', that emerge point to a politics articulated in conjunction with a retinue of nonhuman bodies, technologies and devices interfacing with a lively earth. ${ }^{9}$ Responses from biogeographers have been sympathetic, but lukewarm, although the field has internally grappled with questions of human influence on the dynamics and distribution of life, which is witnessing a revival with the demarcation of the so-called Anthropocene. ${ }^{10}$

If more-than-human geography's persistent reworking of the earth/life nexus has resulted in some of the most vibrant current geographical scholarship, what might it mean to read the forgotten work of Friedrich Ratzel, writing at a time when divisions between the bio and the geo were not firmly settled? And what might such a reading offer for accounts of life and the world which refuse to bracket off the human from rest of the nature? It is these questions that this commentary seeks to address. Firstly, the paper seeks to understand Ratzel's exegesis of the

American snake in the wildlife pet trade and the production of assemblage biogeographies, Annals of the Association of American Geographers 103 (2013) 417-436.

9 M. Barua, Bio-geo-graphy: landscape, dwelling and the political ecology of human-elephant relations, Environment and Planning D: Society and Space 32 (2014) 915-934.

10 P. Jepson, M. Barua, R.J. Ladle and K. Buckingham, Towards an intradisciplinary bio-geography: a response to Lorimer's 'lively biogeographies' of Asian elephant conservation, Transactions of the Institute of British Geographers 36 (2010) 170-174; R.J. Ladle and R.J. Whittaker, Conservation Biogeography, Oxford, 2011; I.G. Simmons, Biogeography: Natural and Cultural, London, 1979; C. Capinha, F. Essl, H. Seebens, D. Moser and H.M. Pereira, The dispersal of alien species redefines biogeography in the Anthropocene, Science 348 (2015) 1248-1251. 
earth/life nexus through the more immediate concerns of more-than-human and contemporary biogeography. Secondly, the paper examines what conceptual purchase, if any, might be drawn from such a reading. Ratzel is seldom considered a canonical figure in biogeography, and neither was he in dialogue with the historical materialist tradition that had emerged in the nineteenth century, and which was to have significant bearings on later geographical writing on landscape. ${ }^{11}$ His renderings of the earth/life nexus and how it is politically molten are fraught with colonial overtones and a disastrous twentieth-century reception. ${ }^{12}$ Yet, histories of geography matter, and the geographies we think geographies with matter even more. Reading the Lebensraum essay thus enables us to pick over the political histories of biogeography and to think carefully about how relations between earth/life emerged as a geographical concern. Accordingly, the next section locates Ratzel, and the Lebensraum essay, within the wider field of biogeography and outlines his understandings of space. Whilst there is much work on his importance within political geography, biogeographical readings of Ratzel remain rare. ${ }^{13}$ The following three sections then address key themes in Ratzel's essay that resonate with contemporary more-than-human geography and its reworking of the bio and the geo. These are the spatial ontologies of animal life, animals' mobilities and cartographies of the living world. I highlight key points in a brief conclusion and

11 On discussions of the biogeography canon, see M.C. Ebach, Origins of Biogeography: The Role of Biological Classification in Early Plant and Animal Geography, Dordrecht, 2015. On Ratzel and historical materialism see J. Verne, The neglected 'gift' of Ratzel for/from the Indian Ocean: thoughts on mobilities, materialities and relational space, Geographica Helvetica 72 (2017) 8592. Verne makes the argument that Ratzel developed his own form of cultural historicism which moved away from culture as evolutionary passage to one of historical connection. For landscape, see D.E. Cosgrove, Towards a radical cultural geography: problems of theory, Antipode 15 (1983) 1-11. The webbed genealogies of the earth/life theme and its persistence in different currents of geographical thought, although beyond the scope of this paper, are certainly a subject for future scrutiny. Two brief points illustrate this. Firstly, Ratzel's writings influenced early twentieth-century Marxists such as Plekhanov and Kautsky who sought to factor the environment into historical materialist analyses. See M. Bassin, Nature, geopolitics and Marxism: ecological contestations in Weimar Germany, Transactions of the identify avenues for future research and engagement.

\section{The bio and the geo I: earthbound}

Ratzel's Lebensraum essay, although more widely discussed in political geography, is subtitled 'a biogeographical study'. Concerned with how organisms are distributed over the surface and history of the earth, the term 'biogeography' came into use towards the end of the nineteenth century. ${ }^{14}$ Some attribute the German coinage of the term biogeographie to Ratzel, purportedly in a letter to Hugo Eisig in 1888, but it was used by others before that, being coined independently in German and English in 1883 and 1892 respectively. ${ }^{15}$ Ratzel's key intervention was that he wanted to unify the plant and animal geographies of his time in the form of a general or an Allgemeine Biogeographie. 'It is the duty of geography', he wrote, 'to go ahead and summarize and create a biogeography that shares a single common principle, to study the distribution of life on Earth'. Such an endeavour required geographical synthesis, for Ratzel saw biogeography as a geographical science. As he argued, once a zoologist asks 'where do these animals live?' and 'what climatic factors and soils influence their distribution?' the science becomes geographical. 16

An important theme in the Lebensraum essay, and one that needs to be read in conjunction with Ratzel's attempt to develop a general biogeography, is the relation between a

Institute of British Geographers 21 (1996) 315-341. Secondly, Ratzel influenced the work of Carl Sauer whose emphasis on the landscape as 'living' has been picked up by more-than-human geography in its attempt to go beyond historical materialism's tendency to render landscapes inert. See C.O. Sauer, The formative years of Ratzel in the United States, Annals of the Association of American Geographers 61 (1971) 245-254 and S. Whatmore, Materialist returns: practising cultural geography in and for a more-thanhuman world, Cultural Geographies 13 (2006) 600609.

12 Bassin, Nature, geopolitics and Marxism.

${ }^{13}$ W. Natter, Friedrich Ratzel's spatial turn, in: H. van Houtum, O. Kramsch and W. Zierhofer (Eds), B/Ordering Space, Oxford, 2013, 171-186.

${ }^{14}$ Brown and Lomolino, Biogeography.

15 G.H. Müller, Ratzel et la biogéographie en Allemagne dans la deuxième moitié du XIXe siècle, Revue d'histoire des sciences 45 (1992) 435-452; Ebach, Origins of Biogeography.

16 F. Ratzel, Anthropogeographie, Stuttgart, 1891, xxiv, cited in Ebach, Origins of Biogeography, 3. 
finite earth and dynamic life. Space for Ratzel is isotropic, but not infinite: 'everything that wants space on our planet earth must draw on this finite amount of 506 million square kilometres of its surface'. 'This number', he argues, 'represents the first spatial factor where the history of life is concerned, and it also represents the last'.17 The rule-like nature of this early twentieth-century formulation has had bearings on modern biogeographical analyses, evident in continual debate on what is known as the species-area relationship - a curve describing the relationship between the area of a habitat and the number of species found within it. Biogeographers disagree on the curve's asymptote, but concur that it has limits at both ends. ${ }^{18}$ The finitude of space, a constant refrain in Ratzel's essay and a basis of his environmental determinism, sets up the evolutionary theatre of life, one that is 'principally determined by its confinement'. Whilst life continually 'surges against those limits', it 'never breaks through them, for it is earthbound'.19

Ratzel does however remark that the earth's surface is not 'entirely unchangeable throughout the formation of the earth', and that the 'earth grows'.20 But for purposes of developing biogeographical rules, he presumes surface area to be essentially stable, 'a constant parameter underlying life in its ever-changing nature'. ${ }^{21}$ 'Internal properties' of the earth act jointly to 'maintain living conditions in an uninterrupted fashion', but living space, or Lebensraum, is 'changing constantly', at multiple scales from 'the living envelope of the soil' to the earth as a whole. Life has bearings upon space: the 'mutability' of its foundations 'uninterruptedly [transform] external living conditions'.22 What emerges then is a vital dynamic between the bio and the geo. Surface might be limited in area, but Lebensraum is in a process of incessant becoming, continually undergoing transformation through relations between earth and life.

\footnotetext{
17 Ratzel, Lebensraum, 2.

18 M.V. Lomolino, Ecology's most general, yet protean pattern: the species-area relationship, Journal of Biogeography 27 (2000) 17-26.

${ }^{19}$ Ratzel, Lebensraum, 3.

20 Ratzel, Lebensraum, 2.

${ }^{21}$ Ratzel, Lebensraum, 3.

22 Ratzel, Lebensraum, 3 and 4.

${ }^{23}$ Sauer, Formative years of Ratzel.

24 Ebach, Origins of Biogeography; J. Browne, Biogeography and empire, in: N. Jardine, J. Secord and E. Spary (Eds), Cultures of Natural History, Cambridge, 1996, 305.
}

I will return to the implications of this dynamic later, but three wider points on how surface relates to bio- and more-than-human geography can be touched upon here. Firstly, modern biogeography, as an observational and synthetic science, deals with space and time at large scales that make experimental manipulation difficult. Ratzel's expositions are within this observational mode, although they go beyond modern biogeography's synthetic tendencies for he combines ethology and ethnology, biology and culture, in ways not evident in contemporary biogeographical work. These in part emerged through his extensive travels in America and elsewhere, and were in part enabled by the volume of natural history observations brought about by expanding European colonialism. ${ }^{23}$ Although biogeographers writing histories of their own discipline argue that colonialism did not influence scientific aims and internal biogeographic debates, the biogeographical sciences of the time were 'forged on the anvil of colonization', the enterprise of empire facilitating observations, collections and measurements. ${ }^{24}$ It needs to be kept in mind that Ratzel, whilst neither antiSemitic nor misogynist, was a supporter of German colonialism in Africa. ${ }^{25}$

Secondly, treating surface area as constant chimes with much of modern biogeographic thought, including Robert MacArthur and Edward Wilson's field-defining equilibrium theory of island biogeography. ${ }^{26}$ Only more recently are biogeographers beginning to attend to the ephemerality of space, witnessed for instance in the gradual appearance and disappearance of oceanic islands, that are now being accounted for in dynamic models of the equilibrium theory. ${ }^{27}$ Thirdly, human geography conceptualizes space as relative or relational. ${ }^{28}$ An apt criticism directed at Ratzel is that there is

25 D.T. Murphy, 'Retroactive Effects': Ratzel's spatial dynamics and the expansionist imperative in interwar Germany, Journal of Historical Geography 61 (2018) ???.

${ }^{26}$ R.H. MacArthur and E.O. Wilson, The Theory of Island Biogeography, Princeton NJ, 1967.

27 R.J. Whittaker, K.A. Triantis and R.J. Ladle, A general dynamic theory of oceanic island biogeography, Journal of Biogeography 35 (2008) 977-994.

28 D. Harvey, Space as a keyword, in: N. Castree and D. Gregory (Eds), David Harvey: A Critical Reader, Oxford, 2006, 270-293; D. Massey, For Space, London, 2005. 
a spatial determinism in his work. ${ }^{29}$ What is not evident, however, is spatial separatism, the cleaving of space into distinct domains of nature and society. This is an important point of tension, for the earth/life dynamic he sets up does not gravitate toward a simple Euclidean understanding of space, out there and inert. Rather, the Lebensraum essay, at moments, suggests that space is an outcome of the dynamic between life and earth. ${ }^{30}$

\section{The bio and the geo II: oecumene or the spatial ontology of the animal}

A rich point of potential engagement between contemporary more-than-human geography and Ratzel's exposition of the earth/life nexus touched upon above is what he terms the 'oecumene' of a plant or animal. Life for him is 'firstly an internal fact of the organism', closely linked to its anatomical constitution. The Lebensraum essay is littered with thick descriptions of different locomotor apparatuses. We read about 'flagellas, air bladders, sails ... tools for flying, creeping, walking and climbing'. Each of these organs is differentially put to the task of spatialization. He describes a 'plant's ramification and a coral's branching', 'the twoleaf germ of an oak' and 'the dividing and budding coral', each of which is a 'manifestation of life and the hallmark of life'. Ratzel goes on to argue that 'it is not only the organs of locomotion that are put to this service, but all organs; each and every advancement benefits the claim for space'. ${ }^{31}$

What this points to, one might contend, is a spatial ontology of the animal. The term oecumene, which Ratzel deploys to characterize the living space or Lebensraum of human beings, derives from the ancient Greek verb oikéo

29 R. Peet, The social origins of environmental determinism, Annals of the Association of American Geographers 75 (1985) 309-333.

${ }^{30}$ Klinke, Re-reading Ratzel.

${ }^{31}$ Ratzel, Lebensraum, 5 and 12.

32 Oecumene|ecumene, Oxford English Dictionary, Oxford, 2004.

${ }^{33}$ An exegesis of Ratzel's concept of the oecumene and his formulation of an anthropogeography is admirably dealt with in C. Santini, At the origins of modern geography. The oecumene: an anthropogeographical pattern, History of European Ideas 43 (2017) 560-569. Santini, whilst talking about a historical and dynamic human oecumene, argues that the term is not simply deployed to mean the world or the surface of the Earth, but rather, is a description of how people conceive their own world and experience it in polyvalent ways. meaning 'to inhabit' or 'to dwell'. It initially referred to the inhabited earth or the 'civilized world' then known to ancient Greeks. ${ }^{32}$ An oecumene is simultaneously a modality of inhabitation and a map of dwelling. ${ }^{33}$ But contrary to perspectives that reserve modalities of inhabitation to humans alone, relegating animals to be occupants of an already laid-out world, Ratzel argues against the current of later twentieth-century human exceptionalism to state that 'every species of plant and animal ... has its oecumene'. Just as human beings with their 'upright walk', sense and make their way through the world in particular ways, animals too, whether 'an amoeba, a coral, a pelagic jellyfish, [or] a land snail', spatialize in their own dynamic ways. ${ }^{34}$

'Even if we do not have a detailed grasp of this space', Ratzel writes, 'we know for sure that it belongs to the plant, the animal'.35 How nonhuman animals spatialize, and the ways in which they inhabit the world according to their own quotidian rhythms and ethophenomenologies, has been a concern of morethan-human geography grappling with questions of nonhuman spaces or 'beastly places', attentive to the lived geographies and experiences of animals, in order to foreground political ecologies of inhabitation attuned to animals' dispositions and rhythms. ${ }^{36}$ Much of the fodder for such articulations has come from the biosemiotics of Jacob von Uexküll, a politically problematic early twentieth-century figure, who argued, contrary to prevailing currents of the time, that animals make meaning of the world, albeit in registers attuned to their own perceptual and phenomenological apparatuses. For von Uexküll, an animal fits the world to itself by ascribing functional qualities to the things it encounters,

34 Ratzel, Lebensraum, 13. For arguments on inhabitation and the nonhuman, see Barua, Bio-geography, and T. Ingold, The Perception of the Environment: Essays on Livelihood, Dwelling and Skill, London, 2000.

35 Ratzel, Lebensraum, 13.

36 S. Hinchliffe, M.B. Kearnes, M. Degen and S. Whatmore, Urban wild things: a cosmopolitical experiment, Environment and Planning D: Society and Space 23 (2005) 643-658; C. Philo and C. Wilbert (Eds), Animal Spaces, Beastly Places: New Geographies of Human-Animal Relations, New York, 2000; Barua, Biogeo-graphy; S. Hinchliffe, Inhabiting: landscapes and natures, in: K. Anderson, M. Domosh, S. Pile and N.J. Thrift (Eds), The Handbook of Cultural Geography, London, 2003, 207-226. 
thereby integrating them into a coherent system of its own. This world, constituted by an organism's perception and action, was what he called the Umwelt. ${ }^{37}$ His work has not only had its reception in geography, but in ecological anthropology and continental philosophy. ${ }^{38}$

The notion of the Umwelt is akin to that of a phenomenological bubble: a creature is so wrapped up in it that no other worlds are accessible to it. ${ }^{39}$ In contrast, Ratzel's oecumene is relational and open to the environment, perhaps more attuned to a geographical disposition that seeks to slough off purely humanist or constructivist notions of space. Unlike the enclosed bubble of the Umwelt, which directs emphasis from the environment to the side of the perceiving organism, the notion of the oecumene is one that articulates a spatial ontology of the animal, where the organism, its 'internal facts', and space are not dissociable. As Ratzel puts it, 'clearly space is something that lies outside the organism, and yet each living thing is bound to its space and connected to its space'. ${ }^{40}$ The oecumene, furthermore, is not a simple model of an anatomical apparatus fitting into space: it entails multiplicity, and a multiplicity produced through relation. As Ratzel writes, 'If every living organism takes up a space in which to dwell, it needs another space from which to draw its food, and it attains the height of its claim for space in the process of reproduction'. ${ }^{41}$

More-than-human geography's accounts of the beastly places of animal life, or the 'lively spaces' of wildlife in spatial formations of movement and exchange, in some ways annul the multiplicity that the Ratzelian concept of the oecumene offers up. ${ }^{42}$ A much more varied and heterogeneous disentangling of the beastly in beastly places could come to the fore with Ratzel's spatial ontology of the animal. Take for instance the oecumene of an elephant. Their large bodies

${ }^{37}$ J. von Uexküll, A stroll through the worlds of animals and men, in: C. Schiller (Ed.), Instinctive Behaviour, New York, 1957, 5-80 and J. von Uexküll, The theory of meaning, Semiotica 42 (1982) 25-82.

38 T. Ingold, Being Alive: Essays on Movement, Knowledge and Description, London, 2011; B. Buchanan, Onto-Ethologies: The Animal Environments of Uexküll, Heidegger, Merleau-Ponty, and Deleuze, Albany NY, 2008.

39 Ingold, Being Alive and Buchanan,Onto-ethologies.

${ }^{40}$ Ratzel, Lebensraum, 13, emphasis in original.

41 Ratzel, Lebensraum, 12.

42 Whatmore, Hybrid Geographies.

${ }^{43}$ R. Sukumar, The Living Elephants: Evolutionary

Ecology, Behaviour and Conservation, Oxford, 2003. and herbivorous diet posits home ranges operating at expansive scales, which exceed the geographies dictated by humans. ${ }^{43}$ Yet intra-herd dynamics and the Proboscidean proclivity for anthropogenic crops can result in the inhabitation of much smaller home ranges by certain populations. ${ }^{44}$ Geographical work on elephants in postcolonial landscapes fissured by mining shows how stressed animals frequent human habitation, often in search of intoxicants such as alcohol, thereby spatializing in ways that completely unsettle the humanist design of conservation landscapes delineating protected areas and elephant corridors. ${ }^{45}$ Each of these modes of inhabitation point to variegated beastly places forged in relational terms. The oecumene enables geographers to retrieve what is spatial about elephants' lives - the ways in which they differentially apprehend the world and make meaning of it - not as bounded entities wrapped in a phenomenological bubble, but as a locus along transversal lines of becoming. Mapping the oecumene brings other lived worlds to life. 46

However, the Lebensraum essay contains a leap from animal to human worlds that fails to account for asymmetric social relations underpinning the claim for space. Ratzel describes how 'a small Indian tribe in the South American virgin forest has needs and expectations regarding space that are very different from those of a European', for whom 'wellbeing can only lie in grasping the whole world'. 47 Together with his environmental determinism, there is this associated problem of naturalizing earth/life relations and mapping them uncritically onto society that does not lie anywhere close to the imperatives of posthumanist geographies and their attempts to delineate new cartographies of life. An encounter with this Ratzelian concept is thus fraught with ethical burdens. ${ }^{48}$

${ }^{44}$ Barua, Bio-geo-graphy.

$45 \mathrm{M}$. Barua, Volatile ecologies: towards a material politics of human-animal relations, Environment and Planning A 46 (2014) 1462-1478.

$46 \mathrm{~J}$. Gerlach, Lines, contours and legends: coordinates for vernacular mapping, Progress in Human

Geography 38 (2014) 22-39.

${ }^{47}$ Ratzel, Lebensraum, 13.

${ }^{48}$ This is also the case for von Uexküll's notion of the Umwelt which fed into his formulation of the state as an organism from which 'parasitic' Umwelten needed to be eliminated, see M. Stella and K. Kleisner, Uexküllian Umwelt as science and as ideology: the light and the dark side of a concept, Theory in Biosciences 129 (2010) 39-51. 


\section{The bio and the geo III: mobility or life as movement}

'Life', Ratzel writes, 'is movement'. The oecumene of an organism, its 'internal facts', also generates 'external movement': 'every increase in organic mass, every growth, every reproduction signifies spatial movement'. ${ }^{4}$ There is a strong vitalist tendency in Ratzel that brings into stark relief much more recent writings on life and the politics of liveliness within geography and beyond. ${ }^{50}$ Contrast Ratzel's assertion that 'movement is expressed in all definitions of life', and that 'Life's movement ... overflows in all directions', with the contemporary anthropologist Tim Ingold's contention that 'life, in short, is a movement of opening'. ${ }^{51}$ Whilst not situated in any neo-vitalist camp, Ingold's summation has an uncanny resemblance to that of Ratzel. The theme of life and movement, a persistent current in the modern social sciences, is something that Ratzel delves into in considerable detail. It has bearings upon a contemporary concern of both more-than-human geography and biogeography: the mobility of nonhuman life.

Expanding upon the concept of the oecumene, life and movement for Ratzel is 'omnidirectional'. ${ }^{2}$ He takes pains to emphasize that animals are not sedentary, but immersed in a world of movement, either induced by humans or independent of them. An eloquent description of the latter is found in his description of spiders' webs 'that have been seen wafting more than a hundred kilometres across the sea ... like miniature balloons: a small spider sits in the gondola ... thus making its journey. Spiderlings flying with the gossamer threads of our Indian Summers correspond to the mobile larval stage, though many of those tiny spiders will never mature to weave any more webs'. But there is something else going on with mobility: 'every movement is a mastering of space'. Here, the link between the bio, geo and politics start to surface, for life and earth get freighted with notions of power and domination. 'Do we not have the right to ask', Ratzel goes on to say, 'whether the mastering of space is generally a manifestation of life and the hallmark of life?'53

Movement enables creatures to adapt, and a 'tendency to roam' prevents organisms

\footnotetext{
${ }^{49}$ Ratzel, Lebensraum, 5.

${ }^{50}$ Klinke, Re-reading Ratzel.

${ }^{51}$ Ratzel, Lebensraum, 5 and Ingold, Being Alive, 4.

52 Ratzel, Lebensraum, 5.
}

from becoming extinct. Ratzel's notion is that there is a wider aim of 'maintaining an acquired place', an act or capacity that is differentiated according to the organism concerned: 'weaker organisms spontaneously latch onto strong ones and, as part of their entourage they conquer spaces they could never gain by themselves'. He thus makes a wider point about human-induced mobility, although the language is couched in terms such as 'weak' and 'strong'. Citing the example of the common rat, Ratzel states that 'few other animals display a distribution so deeply marked by their connection to humans'. ${ }^{54}$ Furthermore, binary divisions between Nature and Culture, associated with modern geographical imaginations, were never quite settled in Ratzel. ${ }^{55}$ As a biogeographer, he was acutely aware of the effects humans had on the movement of animals and plants. 'The most noticeable impact on the living conditions of oldestablished species', Ratzel goes on to state, 'is that which is developed and restructured by culture; before our eyes it creates new living conditions for the immigrants that culture brings'. Through cultivation, humans become agents of these conditions: 'in all cultivated lands in the Tropics the number of species has grown significantly thanks to the introduction of socalled weeds that are common to such distant parts of the world as India, eastern Africa and the Antilles. Add the great number of plants that used to be sparse in the wild, but that proliferates suddenly and intensely on cultivated land. This is how plants from North and South American forests and meadows have become weeds in Germany'. What emerges as a result are altered faunas of entire continents: 'America has experienced a Europeanization of its fauna and flora'. ${ }^{56}$

These effects of humans on animal movement and migration have been taken up in the interpretive social sciences in a number of ways. Alfred Crosby, for instance, argues that 'portmanteau biota' were crucial to the success of European colonialism since they helped create 'versions of Europe' in the colonies. This is not dissimilar to Ratzel's account of the Europeanization of faunas, albeit set within a very

\footnotetext{
53 Ratzel, Lebensraum, 5 and 6.

${ }^{54}$ Ratzel, Lebensraum, 7.

55 Whatmore, Hybrid Geographies.

56 Ratzel, Lebensraum, 4 and 15.
} 
different politics of ecological analysis. 57 Others suggest that human-induced mobility has led to the emergence of 'cosmopolitan faunas', generating beastly places that are no longer parochial but dispersed and distributed the world-over, often with disturbing and unsettling effects. ${ }^{58}$ Such effects are echoed by Ratzel in the Lebensraum essay, albeit in naturalizing and jarring prose: 'Just as Negroes [sic] have become native to Jamaica, where Carib tribes had lived before, so the Indian grey mongoose - introduced to exterminate Jamaican snakes, has taken the upper hand in a detrimental manner'. ${ }^{9}$ Recent biogeographical work is in fact beginning to suggest that human-mediated dispersal, sometimes ten thousand times faster than the background rate, is causing a breakdown of biogeographic barriers, resulting in new biogeographies of an Anthropocene.60

\section{The bio and the geo IV: cartographies of life}

Ratzel's thesis on the relation between the bio and the geo culminates in a tension, one 'between the movement of life which never rests and space on earth which does not change'. From this tension, 'the struggle for space is born'. Ratzel thus provides a spatial logic to Darwinian evolution. 'The struggle for existence', he states, echoing a Malthusian dictum, 'primarily means nothing more than a struggle for space'. ${ }^{61}$ Thus the three themes of finite space, the oecumene and mobility discussed above, come together to constitute a dynamic where the bio, geo and politics begin to interweave. At work here is an earth/life politics that has to do with conquest and colonization. This final section traces some of its cartographies.

The Lebensraum essay has extensive discussions of how animals and plants territorialize, and there are very specific cartographic tropes at work. Distributions according to Ratzel can be 'harmonious' when the

\footnotetext{
${ }^{57}$ A.W. Crosby, Ecological Imperialism: The Biological Expansion of Europe, 900-1900, Cambridge, 2004.

58 M. Barua, Circulating elephants: unpacking the geographies of a cosmopolitan animal, Transactions of the Institute of British Geographers 39 (2014) 559-573; N. Clark, The demon seed: bioinvasion as the unsettling of environmental cosmopolitanism, Theory, Culture and Society 19 (2002) 101-125.

${ }^{59}$ Ratzel, Lebensraum, 15.

${ }^{60}$ A. Ricciardi, Are modern biological invasions an unprecedented form of global change? Conservation
}

living spaces of animals are 'partitioned' from one another. Harmony is disrupted when animals or plants begin a process of 'expansion'. This process, he argues, is not one of 'migration' but 'colonization'. The former entails 'schematic migration paths as clusters of lines departing from one point and reaching another point'. Whilst 'a single plant or animal may travel along such paths, a people, a race, a species can only migrate by colonizing'. Furthermore, climatic and morphological changes 'continuously affect living spaces' eliciting 'great movements of their inhabitants'. The choice of the term 'inhabitant' is noteworthy, for a little later he states that 'It appears that the slow, step by step dispersal, which is not mere migration but could be called occupation [Besitznahme] and colonization, is more important, nay absolutely paramount, for the dispersal of life, compared to all the means of passive transport'.62

A cartography of paths, synonymous with 'tracks' and 'lines', has been used extensively in more-than-human geography and the wider social sciences. ${ }^{63}$ It emphasizes a modality of earth/life writing attuned to movement and the openness of life. Ratzel points to unintentional movement - for instance polar bears drifting with ice - as a form of 'passive means of transport', whereas, for him, the collective logics of species movement rest on colonization, the occupation of territory. In the struggle for space, mobility not only has direction, but purpose. Organisms, Ratzel argues, can voluntarily move to 'new dwelling places', sometimes in the form of retreat, where they end up in 'less advantageous regions'.64 The change in emphasis from migration to colonization rests on an inversion of inhabitation to occupation, a cartographic logic that seeps deep into the colonial project.65 Inhabitation is marked by place-binding activities of organisms emerging through their sentient involvement in the world. Occupation inverts this involvement and posits an already-laid out world, gazed upon by a kingly Cartesian subject, upon

Biology 21 (2007) 329-336; Capinha, Essl, Seebens, Moser and Pereira, Dispersal of alien species.

${ }^{61}$ Ratzel, Lebensraum, 14.

62 Ratzel, Lebensraum, 8-9.

63 Barua, Bio-geo-graphy; Gerlach, Lines, contours, legends; M. Barua, Encounter: living lexicon for the environmental humanities, Environmental Humanities 7 (2015) 265-270; T. Ingold, Lines: A Brief History, Abingdon, 2007.

${ }^{64}$ Ratzel, Lebensraum, 15.

65 Ingold, Being Alive. 
whose surface beings can be arranged, confined or expelled. There is thus a tension in the very term Lebensraum: at one moment living space is relational, about human and nonhuman inhabitants immersed in the world, at other points it marks a conquest of space in a world already laid out.

What species seek to do in their struggle for space, Ratzel further explains, is to maintain borders. Political geographers have extensively discussed Ratzel's writings on borders. ${ }^{66}$ Here I want to emphasize some of their biogeographical and more-than-human dimensions. Firstly, Ratzel sees instinct as the trigger for maintaining borders: 'If the Elbe generally separates the carrion crow from the hooded crow', it is not because the river is a biogeographic barrier, but because of 'the instinctive maintenance of certain borders'. ${ }^{67}$ Here again, the emphasis is displaced onto the agency of the organism - albeit in the form of instinct - making it difficult to argue that Ratzel's thesis was entirely one of spatial determinism. Secondly, borders are not fixed. They are the product of a constant process of territorialization, negotiated by both humans and nonhuman animals. As Ratzel puts it, 'Borders are not to be understood as dividing lines but as fringes, for only if they are spatially distinct ... can we understand their status as a natural battle ground in the to and fro of living organisms' shifts in space'. ${ }^{68}$ This is partly maintained, according to Ratzel, by the 'density of habitation', a volumetric rendition that accounts for the 'intensity' at which organisms occupy the world and hold onto borders. Contrary to some of his contemporaries, density was an important marker of the 'biogeographical peculiarity' of territories in Ratzel's analysis, and the alternatives to the delineation of biogeographical realms that he proposed hark back to his calls for integrating animal and plant biogeography. ${ }^{69}$

Thirdly, borders and the struggle for space give rise to 'a tension between the inside and the outside, between the core of the territory and its margins or borderlands'. Here, 'life's grip on the soil becomes weaker' and species are most likely to become extinct in the so-called border regions. ${ }^{70}$ Contemporary biogeographers

\footnotetext{
66 Natter, Friedrich Ratzel's spatial turn.

${ }^{67}$ Ratzel, Lebensraum, 10.

68 Ratzel, Lebensraum, 17.

${ }^{69}$ Ratzel, Lebensraum, 11.

70 Ratzel, Lebensraum, 17.

${ }^{71}$ R. Channell and M.V. Lomolino, Trajectories to extinction: spatial dynamics of the contraction of
}

modeling extinction do talk about similar dynamics, referring to the 'demographic hypothesis' where species, akin to Ratzel's volumetric formulation, are most likely to be abundant in the centre of their range. In this scenario, extinction processes are most likely to take grip in peripheries. The alternate hypothesis is that the contagion-like spread of extinction forces wipe out species at the centre of their range due to connectivity and contact between populations, not dissimilar to the workings of infectious disease vectors. As a result, species persist in isolated pockets at the periphery of their ranges. Indeed, biogeographical models tend to support the latter idea. ${ }^{71}$

However, for Ratzel, the argument on borders quickly moves to a problematic political realm when he suggests a similar logic is at work in human societies. As he argues, 'Historically, no species or race has suddenly died off across a wide territory, but being driven back into ever narrower spaces is in every case an external expression of disappearance. Usually these spaces have also been ones with poorer living conditions'. ${ }^{72}$ Here, uneven power dynamics, integral to how people have been extirpated in many parts of the world, be it through logics of race or colonialism, are occluded. ${ }^{73}$ In lieu, a spatial-deterministic logic is offered whereby stratified social relations that condense people into particular territories lose their import in the analysis.

\section{Conclusions}

This commentary has sought to read Ratzel's Lebensraum essay in light of contemporary more-than-human geography and biogeography, and, in doing so, has engaged with what Ratzel's work might offer up for geographers' continued investment in grappling with the earth/life nexus. It has foregrounded some of the key biogeographical ideas in the essay, reflective of the science of the time, from which Ratzel drew in his attempt to develop a unified field comprising perspectives as disparate as plant and animal biogeography, ethnology and political geography. I have explicitly traced the

geographical ranges, Journal of Biogeography 27

(2000) 169-179.

72 Ratzel, Lebensraum, 16.

73 P. Brantlinger, Dark Vanishings: Discourse on the Extinction of Primitive Races, 1800-1930, Ithaca, 2003. 
spatial dynamics Ratzel espoused, highlighting notions of animals' spatial ontologies, nonhuman mobility and cartographies of the living world. These resonate, albeit uncomfortably, with morethan-human geography's attempts to articulate the politics and dynamics of earth/life. These short expositions have provided a reading of the Lebensraum essay that engages questions otherwise overlooked in political geographers' engagements with Ratzel. ${ }^{74}$ This brief conclusion highlights a few points for future engagement and enquiry.

Ratzel's Lebensraum essay could perhaps be considered part of more-than-human geography's canon, at least in light of its continual investment in understanding the social in terms of the earth/life nexus. Ratzel's career as a biogeographer is less well known, partly because of the paucity of translated works, and partly because biogeography itself has been at the margins of histories of political thought. Tracing relations between biogeography and political geography, refracted through other key figures, including Ernst Haeckel and Moritz Wagner, with whom Ratzel had close links, could yield rich dividends for writing intellectual histories of the geographical tradition.

Formulations of living space, although fraught with political misgivings, enable morethan-human geographers to look to their own tradition for thinking about the cartographies of nonhuman life. Much of the field's recent attempts in this regard have involved drawing from the sciences, and whilst productive, this sometimes fails to appreciate the historical resonances of key concepts. ${ }^{75}$ Ratzel's formulations are riven, one might dare say, with productive tensions. Although there is little doubt that he was a spatial determinist, determinism is only part of the story. As this commentary, and others, highlight, spatial separatism or the bifurcation of space into domains of nature and that of society, does not come into Ratzel's accounts of living space. Rather, space is an outcome of the earth/life dynamic, a dynamic that is constituted by movement. Ratzel's equation of life with movement is a theme that has been revitalized in contemporary social sciences, as have ideas on the Europeanization of faunas brought about by

\footnotetext{
${ }^{74}$ G. Ó Tuathail, Critical Geopolitics: The Politics of Writing Global Space, Minneapolis, 1996; Smith, Friedrich Ratzel.???

${ }^{75}$ M. Gandy and S. Jasper, Geography, materialism, and the neo-vitalist turn, Dialogues in Human
}

human-induced movement, albeit without a direct Ratzelian genealogy. Here too lie contrasting cartographic vocabularies. On the one hand, Ratzel describes paths, the trajectories of inhabitants moving through the world, a language which is later subsumed by the logic of occupants and colonizers in their struggle to master space. These tensions could indeed be used productively, for in many ways they reflect the dynamic between life's capacity to exceed human imposition, that it 'overflows in all directions', and majoritarian logics of capital and expert design that constantly reterritorialize it. ${ }^{76}$

The deployment of Ratzelian ideas generates important ethical concerns, particularly in light of their twentieth-century reception. More recently scholars have pointed out that his contributions to cultural geography, though unnoticed, bear striking similarities to contemporary discussions about mobility, materiality and relational space. By 'neglecting Ratzel's "other" side, we certainly miss an important precursor to contemporary debates in geography'. ${ }^{77}$ Ratzel's concept of the oecumene, as highlighted in this paper, is a case in point. It provides valuable insights for thinking about animals' ontologies, in ways more attuned to a geographical analysis that opens up difference in their beastly spatializations, which emphasizes nonhuman lifeworlds constituted in and through movement, and which foregrounds animals' territorializations with and against the grain of human design, provided correctives to Ratzel's naturalizing tendencies and political logics are adopted. Whilst this commentary and the conversation it has sought to spark have highlighted limitations of Ratzel's ideas, it has also been written in an optimistic vein. Whether its provocations stand up to future rapprochement and interest remains to be seen. A reading of the Lebensraum essay illustrates how concepts developed in more-than-human geography are part of a rich tradition of grappling with how the social emerges through relations with, and the assembly of, earth/life. ${ }^{78}$ The histories of geography indeed matter, and the sorts of geographies we think geographies with ought to matter more.

Geography 7 (2017) 140-144 and Klinke, Re-reading Ratzel.

76 Ratzel, Lebensraum, 5.

77 Verne, The neglected gift, 90.

78 Whatmore, Where natural and social science meet. 